\title{
THE COMBINATION TIME AND TEMPERATURE TO ALOE VERA SKIN TEA AS FUNCTIONAL DRINK
}

\author{
Diterima 7 Oktober 2017; diterima pasca revisi 30 Oktober 2017 \\ Layak diterbitkan 31 Oktober 2017
}

Narsih* dan Agato

Agriculture Technology, Business Administration, State Polytechnic of Pontianak, West Kalimantan 78124

\begin{abstract}
This study gets started by making the dry tea from aloe vera skin. The making of aloe vera skin tea was used the cabinet drying. The stem of aloe vera its green coloring was spread evenly on the surface was stacked on the plastic basket that lined with the paper. The steps were carried out to sorting, cleaning, weighing, and peeling off the stem continued by separating the gel and skin of the aloe vera. The aloe vera skin was dried on the cabinet drying at $60^{\circ} \mathrm{C}$ for 4 hours, then brewed using the water at 70, 80, and $90^{\circ} \mathrm{C}$ for 1 and 3 minutes. The best result from the each parameter such as tannin, phenol, alkaloid, and antioxidant activity would be continued by GCMS test to identify the volatile compounds and the organic acid as the compiler of the brewed tea by using HPLC.
\end{abstract}

Keywords : aloe vera tea skin tea, functional drink, temperature, time

\begin{abstract}
ABSTRAK
Penelitian ini diawali dengan pembuatan teh kering dari kulit lidah buaya yang menggunakan pengeringan kabinet. Batang lidah buaya yang berwarna hijau yang tersebar disetiap permukaan diletakkan di atas wadah plastik yang dilapisi kertas. Tahapan tersebut meliputi penyortiran, pembersihan, penimbangan, dan mengelupas bagian batangnya yang dilanjutkan dengan memisahkan gel dan kulit lidah buaya. Kulit lidah buaya dikeringkan pada pengering kabinet pada suhu $60^{\circ} \mathrm{C}$ selama 4 jam, lalu diseduh menggunakan air pada suhu 70, 80, dan $90^{\circ} \mathrm{C}$ selama 1 dan 3 menit. Hasil terbaik dari masing-masing parameter yang meliputi pengujian aktivitas tanin, fenol, alkaloid, dan antioksidan akan dilakukan pengujian GCMS untuk mengidentifikasi senyawa volatil, dan pengujian menggunakan HPLC untuk mengetahui asam organik yang terkandung dalam the seduh.
\end{abstract}

Kata kunci: Teh lidah buaya, minuman fungsional, suhu, waktu 


\section{INTRODUCTION}

The aloe vera tea was a product from the skin of aloe vera brewed such beverages of the tea as generally. The bioactive component has a special quality to increased the body invulnerability on several diseases, then it can be removed stress, recovered the digestive upsets, and secreted the chemical residue from the body. The aloe vera content included the organic compounds and the bioactive component. The Antioxidant of aloe vera skin was the bioactive component has potential benefits for health (Hamman, 2008). In addition, Theppakorn et al. (2014) reported that the consumption of tea has been related to beneficial health occasioned the presence of catechins and polyphenols as natural antioxidant.

The bioactive component of aloe vera skin according to Narsih et al. (2012), who reported that have the high sensitivity on heat treatment. Therefore, for processing the application product should be using the method appropriately to minimize the loss of the bioactive component. The making process of instant tea from the aloe vera skin as a functional drink influenced by the time and temperature. The combination between both very influenced to the brewed tea quality on the bioactive component. According to Fulder (2004), who reported that the time of brewing more than 8 minutes couldn't have the effect to calm down caused the leaf's tea haven't any content to made it.

The brewing temperature was too low occasioned the bioactive compounds disperse in the parenchymal tissue of plant was not extraction perfectly. In the contrary, the brewing temperature was too high could impair the bioactive component its extracted become another component. In addition, Astill et al.

*Corresponding author:

Narsih

Email :narsih78@gmail.com

Agriculture Technology,Business Administration, State

Polytechnic of Pontianak, West Kalimantan 78124
(2001) reported that chemical compounds such as poliphenol, caffein, tannin, and theaflavin content will reduce cause of the increasing of temperature and time. The decreasing in polyphenol and antioxidant activities occurred at longer times and higher temperatures ( $\mathrm{Su}$ et al., 2007).

Therefore, the study of the time and temperature of brewing was needed to produce the instant functional drink with the high bioactive content, appropriately. Thus, based on the physical and chemical parameter would produced the instant functional drink from aloe vera skin has the positive physiological function for the consumers especially for health.

\section{MATERIAL AND METHODS}

\section{Sample preparation}

The aloe vera skins were preconditioned by cabinet drying at $60^{\circ} \mathrm{C}$ for 4 hours. The aloe vera skin dried, then brewed using water at 70 , 80 and $90^{\circ} \mathrm{C}$ for 1 and 3 minutes. The supernatant obtained was used to concerned parameter analysis. The best result was identified of the volatile compounds and the organic acid by using GCMS and HPLC, respectively.

\section{Determination of tannin content}

The tea from aloe vera skin dried $(1 \mathrm{~g})$ was brewed by $150 \mathrm{~mL}$ of aqua dest at $80^{\circ} \mathrm{C}$ for 3 minutes, then filtered using Whatman filter paper grade no 42. Sample $(0.1 \mathrm{~g})$ was extracted with $5 \mathrm{~mL}$ of acidified methanol $(1 \%$ $\mathrm{HCl}$ in methanol) at room temperature for 15 minutes. The mixture was centrifuged at 3,000 rpm for 20 minutes. About $0.1 \mathrm{~mL}$ of the supernatant was added $7.5 \mathrm{~mL}$ of distilled water, $0.5 \mathrm{~mL}$ of Folin-Denis reagent, $1 \mathrm{~mL}$ of $35 \%$ sodium carbonate $\left(\mathrm{Na}_{2} \mathrm{CO}_{3}\right)$ solution and diluted to $10 \mathrm{~mL}$ with distilled water.

How to cite:

Narsih \& Agato. (2017). The Combination Time and Temperature to Aloe Vera Skin Tea as Functional Drink. Jurnal Ilmu dan Teknologi Hasil Ternak, 12 (2), 103112. 
The mixture was shaken well, kept at room temperature for 30 minutes and absorbance was measured at $725 \mathrm{~nm}$. Blank was prepared with water instead of the sample. Tannin content was expressed as tannic acid equivalent (TAE) in $\mathrm{mg} / \mathrm{g}$ material.

\section{Identification of catechin by TLC}

Thin Layer Chromatography (TLC) was performed for identification of catechin. The concentrated extracts were spotted on the lower side of the TLC plate $(20 \times 20 \mathrm{~cm})$ precoated cellulose plate. The diameter of each spot was about $5 \mathrm{~mm}$. Then TLC was run onedimensionally in the mobile phase solvent (acetate acid at 15\%) at room temperature. The plates were developed and visualizing under UV light at $254 \mathrm{~nm}$.

\section{Determination of volatile compound}

The volatile compound from the brewed of aloe vera skin dried was analyzed using GCMS QP2010S-Shimadzu under the following condition: column used were Rtx-5MS, $30 \mathrm{~m}$ length and inner diameter of $0.25 \mathrm{~mm}$ and the initial column temperature was $70^{\circ} \mathrm{C}$ and final temperature was $280^{\circ} \mathrm{C}\left(5^{\circ} \mathrm{C} /\right.$ minute $)$, while the injector temperature was $300^{\circ} \mathrm{C}$ with split mode injector and split ratio of 72.6 and pressure of $14.0 \mathrm{kPa}$. The flow rate was 40 $\mathrm{ml} /$ minute and the flow within the column was $0.50 \mathrm{ml} /$ minute. The detector temperature was $300^{\circ} \mathrm{C}$ and using Helium as the gas carrier with EI (Electron Impact); and the samples volume injected was $1 \mu \mathrm{l}$. Compounds were identified by comparing retention indices/comparing mass spectra of each compound with those of authentic samples and library. While for functional unit determination the Shimadzu Fourier.

\section{Determination of organic acid}

The organic acid from the brewed of aloe vera skin dried was measured using HighPerformance Liquid Chromatography under the following conditions: column used were inertsil $\mathrm{NH}_{2} \mu \mathrm{m} 250 \times 4.6 \mathrm{~mm}$, and the flow rate was 1 $\mathrm{ml} /$ minute. The column temperature was $30^{\circ} \mathrm{C}$, detector UV $290 \mathrm{~nm}$ and using ethyl acetate/nhexane $30 / 70$ as the gas carrier.

\section{Determination of antioxidant activity (DPPH)}

The sample was analyzed for its antioxidant activity using the DPPH (2,2-diphenyl- 2picrylhydrazyl) radical scavenging assay. The sample $(200 \mathrm{~g})$ was dissolved in $100 \mathrm{mM}$ Tris. $\mathrm{HCl}$ buffer (800 il, $\mathrm{pH} 7.4$ ) followed by the addition of $1 \mathrm{~mL} 500 \mathrm{iM}$ DPPH. The solution was homogenized using a shaker and storage in dark room for $20 \mathrm{~min}$. The spectrophotometry was used to determine the absorbance at 517 $\mathrm{nm}$.

\section{RESULT AND DISCUSSION}

The antioxidant activities of thermal processing on brewed of aloe vera skin dried determined using DPPH assay (\%), total phenol content $(\mathrm{mg} / \mathrm{g})$, tannin content $(\mathrm{mg} / \mathrm{g})$ and catechin content $(\mathrm{mg} / \mathrm{g})$ were shown on Table 1. 
Table 1. The Average of Tannin, Total Phenol, DPPH Assay, and Catechin of Thermal Processed on Brewed of Aloe Vera Skin Dried

\begin{tabular}{c|c|c|c|c|c}
\hline $\begin{array}{c}\text { Different } \\
\text { thermal } \\
\text { processing }\end{array}$ & $\begin{array}{c}\text { Time of thermal } \\
\text { processing } \\
(\text { minutes })\end{array}$ & $\begin{array}{c}\text { Tannin } \\
(\mathrm{mg} / \mathrm{g})\end{array}$ & $\begin{array}{c}\text { Total phenol } \\
\text { content } \\
(\mathrm{mg} / \mathrm{L})\end{array}$ & $\begin{array}{c}\text { DPPH assay } \\
(\%)\end{array}$ & $\begin{array}{c}\text { Catechin } \\
\text { content } \\
(\mathrm{mg} / \mathrm{l})\end{array}$ \\
\hline \multirow{3}{*}{$70^{\circ} \mathrm{C}$} & 1 & 98.432 & 421.902 & 22.671 & 95.480 \\
\cline { 2 - 6 } & 3 & 100.431 & 411.542 & 20.801 & 87.119 \\
\cline { 2 - 6 } & 5 & 118.091 & 396.216 & 17.410 & 72.374 \\
\hline \multirow{3}{*}{$80^{\circ} \mathrm{C}$} & 1 & 123.910 & 374.121 & 16.901 & 64.091 \\
\cline { 2 - 6 } & 3 & 127.458 & 346.127 & 15.689 & 50.326 \\
\cline { 2 - 6 } & 5 & 129.610 & 324.357 & 14.885 & 46.651 \\
\hline \multirow{3}{*}{$90^{\circ} \mathrm{C}$} & 1 & 133.541 & 310.161 & 13.451 & 40.540 \\
\cline { 2 - 6 } & 3 & 142.760 & 301.623 & 11.095 & 31.091 \\
\cline { 2 - 6 } & 5 & 148.991 & 284.762 & 9.951 & 28.593 \\
\hline
\end{tabular}

The result was acquired that the difference of temperature and time on brewed of the aloe vera skin tea have influenced to the increasing of tannin content. The changes of tannin content effected by the difference of temperature and time was shown on Figure 1.

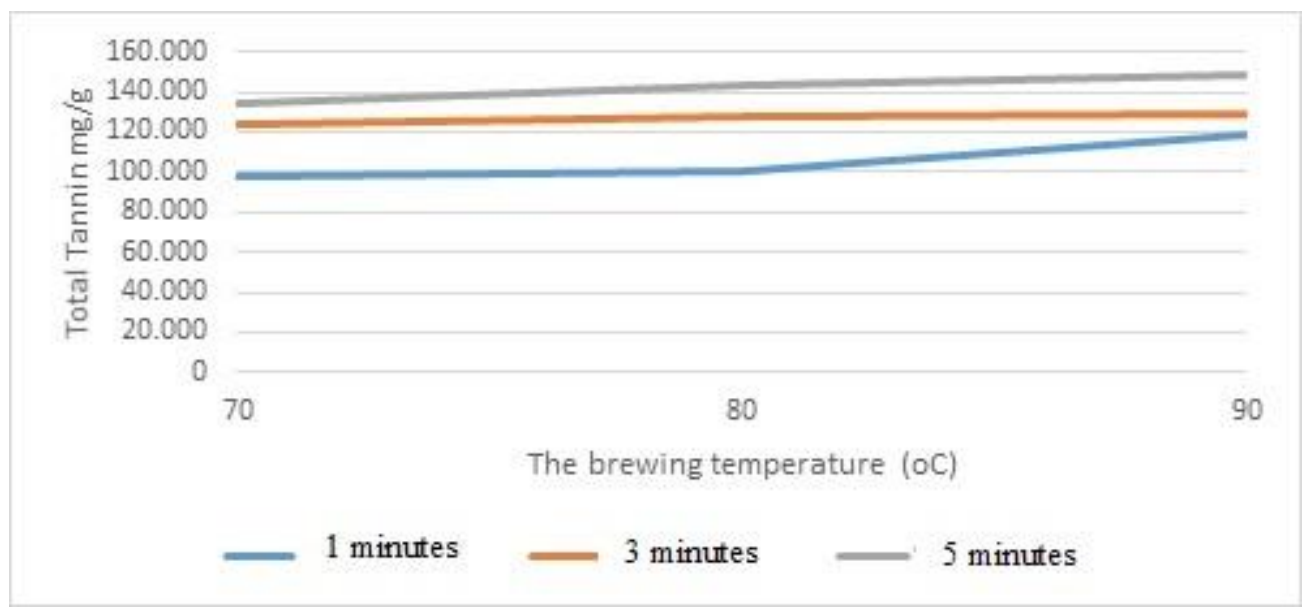

Figure 1. Effect of The Difference Temperature and Time on Brewed of The Aloe Vera Skin Tea to The Tannin Content

\section{Tannin content}

The range of tannin content of thermal processing on brewed of aloe vera skin dried was $98.432-148.991 \mathrm{mg} / \mathrm{g}$. As mention above in Table 1 and Figure 1, several trends were occured. An increase in tannin content was found in thermal processed brewed of aloe vera skin dried at $70-90^{\circ} \mathrm{C}$ for 1 to 5 minutes. And this result was similar to the one reported by Shonisani (2010), who found the tannin content of $1.80 \mathrm{mg} / 100 \mathrm{~g}$ in the samples, which were combination between bush tea and black tea at $90^{\circ} \mathrm{C}$ for 3 minutes could maintain the tannin content. In addition, based on result study of Mache et al. (2015), who reported that the optimum zone of tannins contens (800-2200 $\mathrm{mg}$ ) were obtained for the parameters zone between $65-95^{\circ} \mathrm{C}$ (temperature) and 5-15 minutes (time).

The use of tannic acid as a feed additive up to $15 \mathrm{mg} / \mathrm{kg}$ feed was safe for all animal species. The use of tannic acid as a feed additive under the proposed conditions of use presents no safety risk to consumers. Moreover, tannins have spesific properties which promote their use as natural substances in medicine such as 
antibacterial function, antitumor, antivirus, and antimutagenic function (Luthar and Kreft, 1999). Then, tannin was active component of natural tanning agent and was antioxydant, natural conserving agent, etc. (Luthar and Kreft, 1999).

\section{Total Phenol}

Results of the study found that the difference in temperature and time on brewed of aloe vera skin dried tea has effect of decrease the phenolic content. Differences in the amount of phenolic obtained by differences in temperature and brewed time are shown in Figure 2.

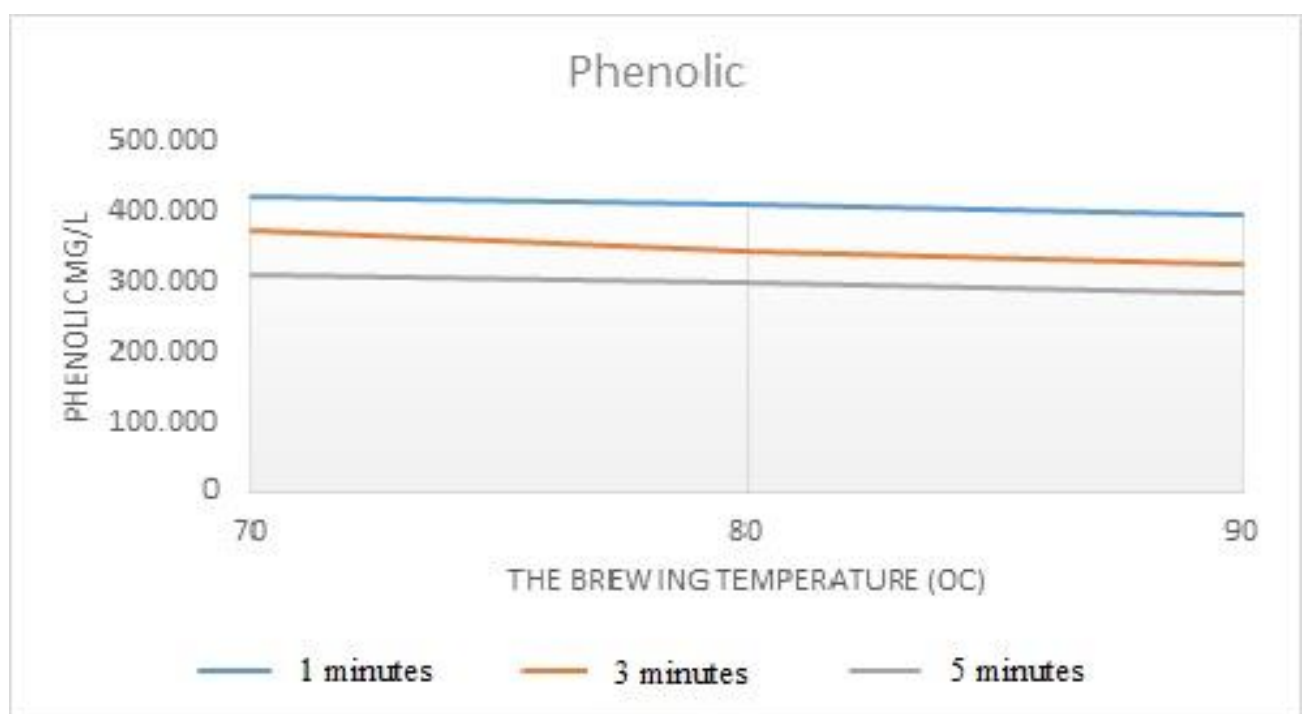

Figure 2. Effect of Difference in Temperature and Time on Brewed of Aloe Vera Skin Dried Tea to The Phenolic Content

The range of phenolic content of thermal processing on brewed of aloe vera skin dried was $284.762-421.902 \mathrm{mg} / \mathrm{L}$. As mention above in Table 1 and Fig 2, several trends have occurred. A significant decrease in phenolic content was found in thermal processed brewed of aloe vera skin dried at $70-90^{\circ} \mathrm{C}$ for 1 to 5 minutes. The highest phenolic content was obtained form thermal processed at $70^{\circ} \mathrm{C}$ for 1 minutes $(421.902 \mathrm{mg} / \mathrm{L})$, while the lowest one was at $90^{\circ} \mathrm{C}$ for 5 minutes $(284.762 \mathrm{mg} / \mathrm{L})$. And this result is similar to one reported by Braud et al. (2015), who found the phenolic content will decrease around $10 \%$ during thermal processing for 5 to 30 minutes. Kara et al. (2014) also noted that the increased of thermal processing could decrease phenolic content at a different temperature and time.
Astill et al. (2001) suggested that the most of the compound in tea brewed such as polyphenol, caffeine, tannin and theaflavin content will reduce cause of the increasing of temperature and time.

Miranda (2009) noted that the damage of phenolic was observed after heating, therefore, phenolic such as flavonoid might be altered become another compound.

\section{Antioxidant Activity Test Results (DPPH)}

Results of the study found that the difference in temperature and time on brewed of aloe vera skin dried tea has effect of decrease the antioxidant activity. Differences in the amount of antioxidant activity obtained by differences in temperature and brewed time are shown in Figure 3. 


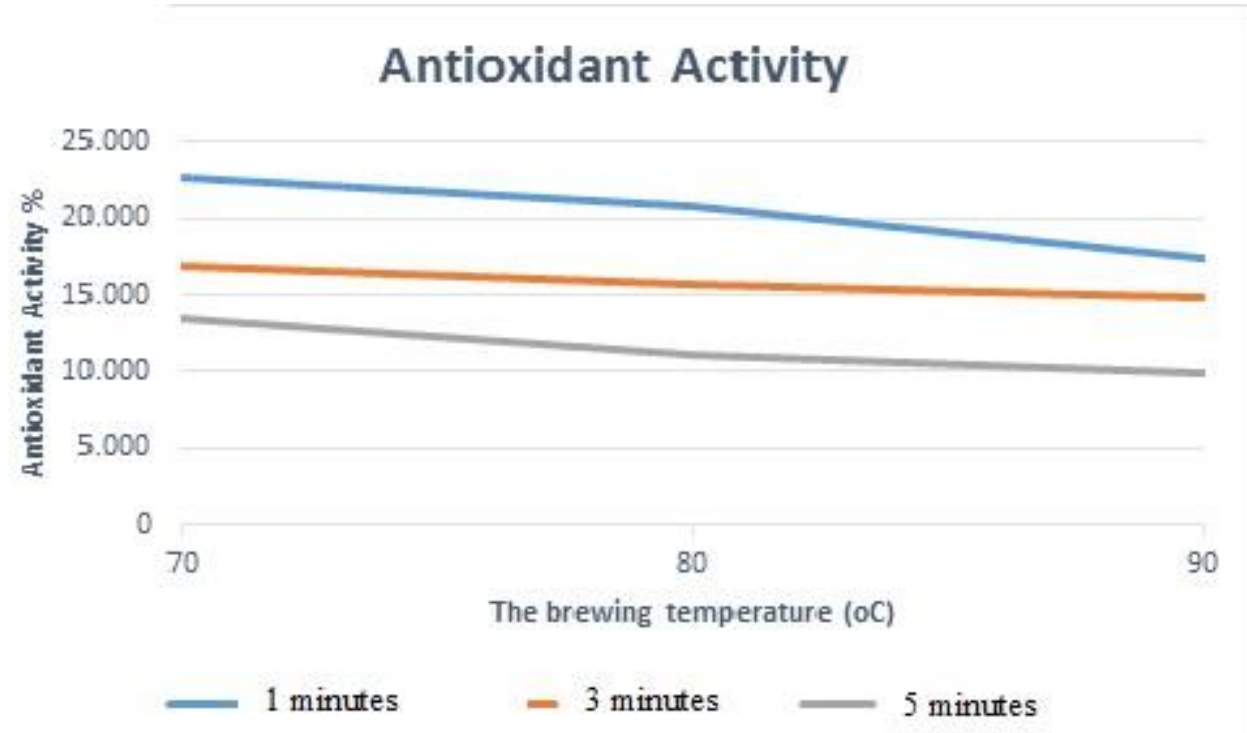

Figure 3. Effect of Difference in Temperature and Time on Brewed of Aloe Vera Skin Dried Tea to The Antioxidant Activity

As mention above in Table 1 and Figure 2, several trends are occurred. A significant decrease in phenolic content was found in thermal processed brewed of aloe vera skin dried at $70-90^{\circ} \mathrm{C}$ for 1 to 5 minutes. The range of antioxidant activity of thermal processing on brewed of aloe vera skin dried determined using DPPH assay (\%) was 9.951-22.671\%. As mention above in Figure 3, several trends are occurred. A decrease in antioxidant activity was found in thermal processed brewed of aloe vera skin dried at $70-90^{\circ} \mathrm{C}$ for 1 to 5 minutes. Kara et al. (2014) reported that radical scavenging activities of Sideritis condensate of aqueous extract at $60^{\circ} \mathrm{C}$ for 5,10 and 30 minutes were statistically in the same group but lower than those of leaves soaked at $100^{\circ} \mathrm{C}$ for 5, 10 and $30 \mathrm{~min}$. Su et al. (2007) also noted that higher temperature and longer time led to the loss of antioxidant activity of oolong tea. Purnomo et al. (2010) suggested that a significant decrease in radical-scavenging activity of thermal processing might be occurred as a decomposition of the active compounds, since the levels of these are quite low in the fresh product, it is more likely that cell damage during the heating process results in the greater release of these compounds.

\section{Catechins Test Results}

Results of the study found that the difference in temperature and time on brewed of aloe vera skin dried tea has effect of decrease the catechins content. Differences in the amount of catechins obtained by differences in temperature and brewed time are shown in Figure 4. 


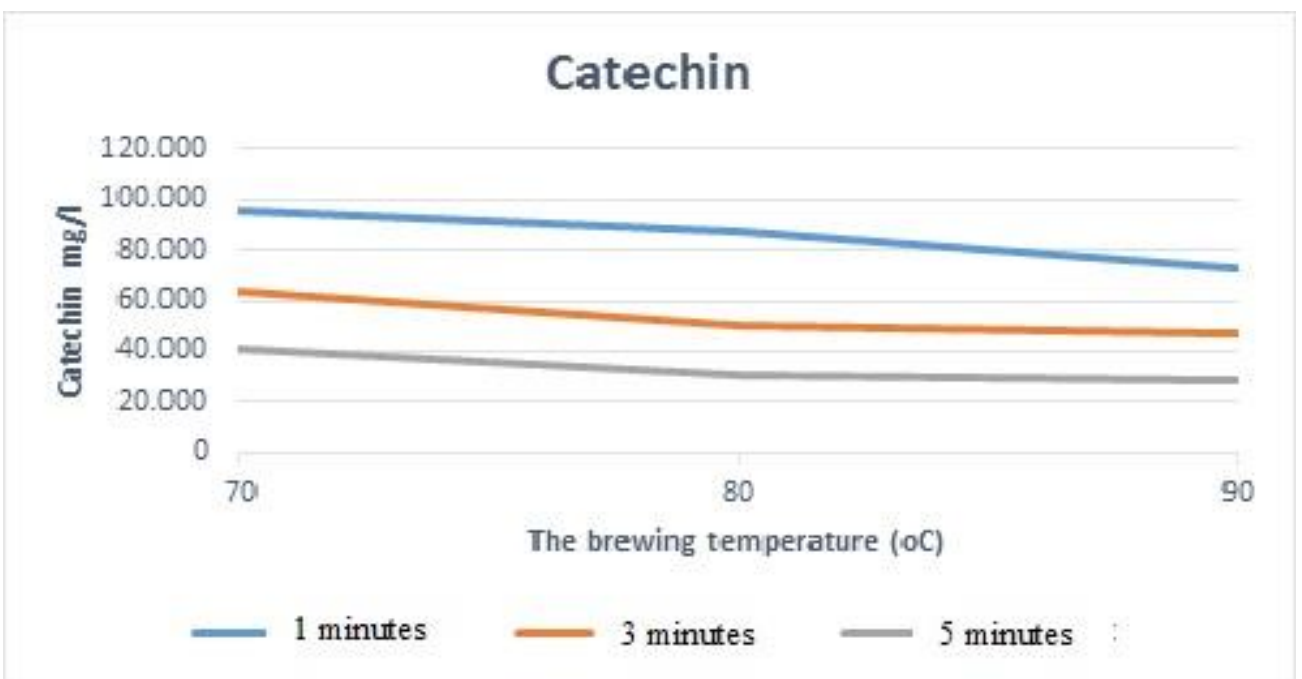

Figure 4. Effect of Difference in Temperature and Time on Brewed of Aloe Vera Skin Dried Tea to The Catechins Content

The range of catechin of thermal processing on brewed of aloe vera skin dried was $28.593-95.480 \mathrm{mg} / \mathrm{L}$. As mention above in Figure 4, several trends have occurred. A significant decrease in catechin content was found in thermal processed brewed of aloe vera skin dried at $70-90^{\circ} \mathrm{C}$ for 1 to 5 minutes. The highest catechins content was obtained form thermal processed at $70^{\circ} \mathrm{C}$ for 1 minutes $(95.480 \mathrm{mg} / \mathrm{L})$, while the lowest one was at $90^{\circ} \mathrm{C}$ for 5 minutes $(28.593 \mathrm{mg} / \mathrm{L})$. And this result is similar to one reported by Saklar et al., (2015) stated that the increase brewed up to temperature $80^{\circ} \mathrm{C}$ for 3 minutes can decrease in the amount of catechins obtained 50,69 $\mathrm{mg} / 100 \mathrm{ml}$. Acording to Figueroa et al. (2004), the range catechins found in green tea were between 35-45\%, in the formepigallocatechingallate. Catechins class of polyphenol compounds that have the activity of biological and functional properties as an antioxidant (Pastore and Fratellone, 2006). According to Matsubara and Rodrigez-Amaya (2006) catechins are compounds that cause a bitter taste.

\section{Volatile Compound}

Results of the study found that the difference in temperature and time on brewed of aloe vera skin dried tea has effect of the volatile compound. Graph of volatile compound detected in treatment is presented in Figure 5.

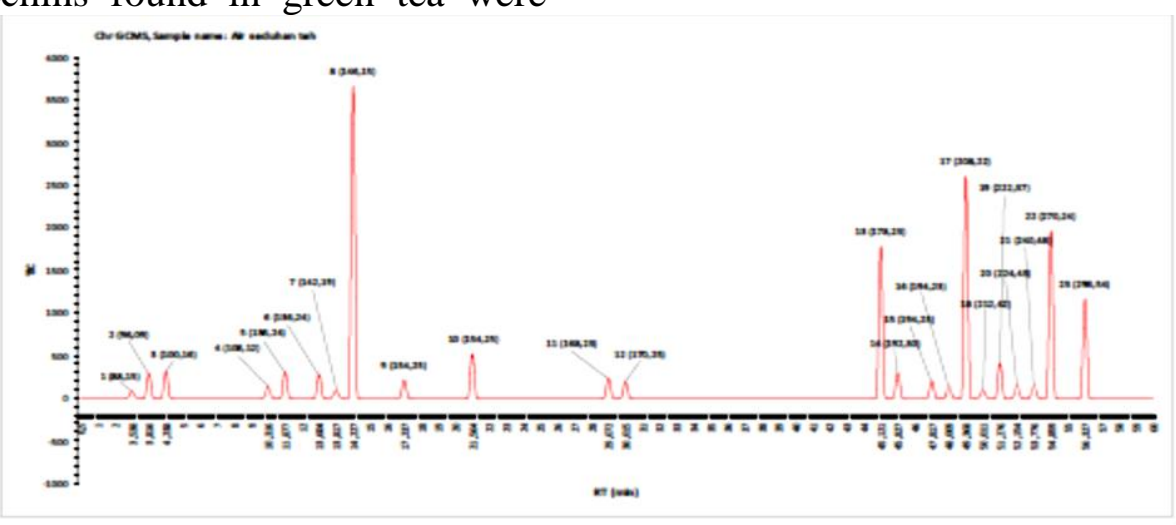

Figure 5. The Best Treatment of Temperature and Time on Brewed of Aloe Vera Skin Dried Tea to The Volatile Compound 
The best temperature and time on brewed of aloe vera skin dried which determined by GCMS assay (\%) was $70^{\circ} \mathrm{C}$ for 1 minute. The most dominant volatile compounds there are five peaks that coumarin compound at the peak of No. 7 (23.92061\%), antroquinone compound at peak no 17 (17.01735\%), aloe emodin compound at the peak of No. 22 (12.82885\%), antracene compound at peak no $13(11.61467 \%)$ and phytol compound at peak no $23(7.58720 \%)$. And this result is similar to one reported by Narsih et al. (2012) who found compound coumarin in bark extract of aloe vera was 7.64\%. According to Mac and Grabber (2002), most of coumaric acid is esterified with lignin and generate biocatalytic aromatic compounds.

The results of volatile compounds on brewed of aloe vera skin dried by GCMS were detected as many as 22 consecutive peaks of these compounds are: 1 pentanol, furfural, Hexanal, benaldehyde, pinene, limonene, 2,3octanedione, coumarin, linalool, a terpinol, geranic acid, linalool oxide, anthracene, $\alpha$ lonone, anthranol, 1-anthrol, anthrouinone, Pentadecane, $\alpha$ cardinal, 1-Hexadecane, heptadecane, aloe emodin. Choi and Chung
(2003) explains that the active component found in aloe vera include carbohydrates, enzymes, organic components and fats (campestrol, phytosterols, $\beta$ - sitosterol), essential amino acids and non-essential proteins, vitamins $(\mathrm{B}, \mathrm{C}, \beta$-carotene, choline, folic acid, $\alpha$-tocopherol), anthraquinones/anthrones (Aloe-emodin, aloetic-acid, anthranol, aloin A and B (known as acid barbaloin) and saponins, while according Arunkumar and Muthuselvam (2009), other active components adalah7tetradecane, methyl ester, n-hexadecanoic acid, squalene, $\alpha$-tocopherol, sitosterol, lupeol, coumaric and components that are volatile at aloe vera skin according Coopoosamy (2010), was limonene, phenylacetronitrile and carvone.

\section{Organic Acids Test Results}

Results of the study found that the difference in temperature and time on brewed of aloe vera skin dried tea has effect of the organic acids compound. Graph of organic acids compound detected in treatment is presented in Figure 6.

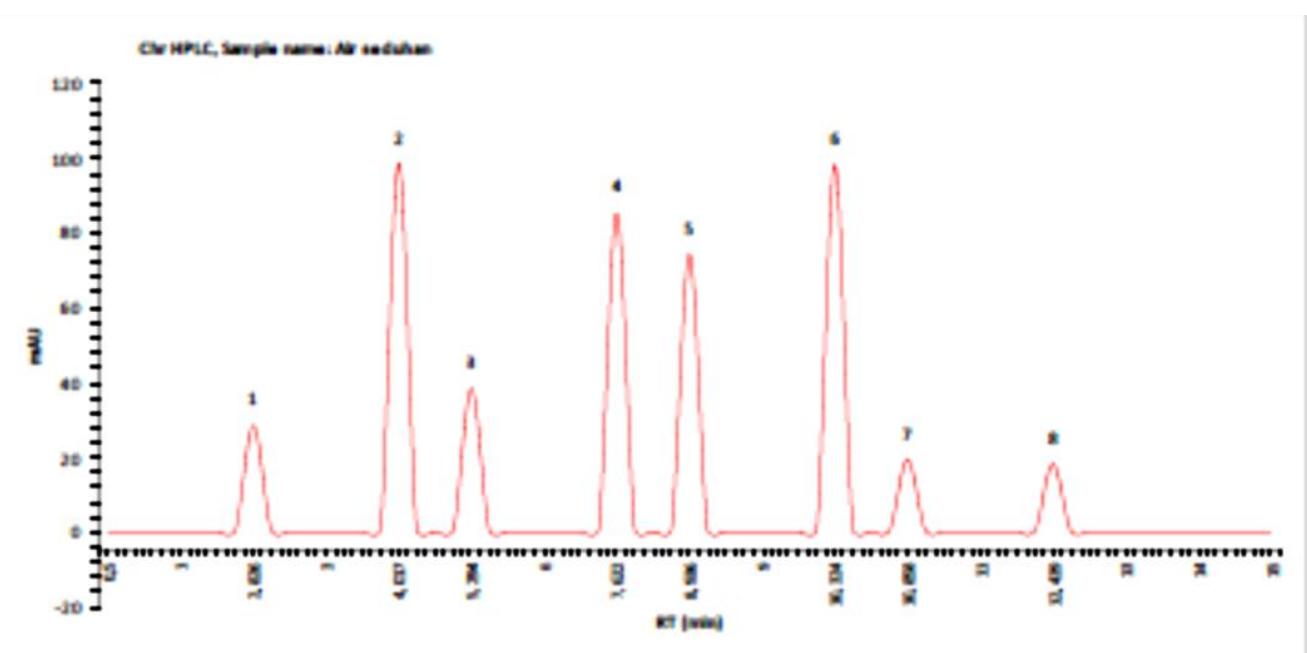

Figure 6. Organic Acids on Brewed of Aloe Vera Skin Dried Tea 
The test results of organic acids on brewed of aloe vera skin dried which determined by HPLC Chromatogram assay (\%) in Figure 5, at $70^{\circ} \mathrm{C}$ and a time of 1 minute covering 8 types of organic acids respectively were formic acid at the peak of the No. 1 was $0,126885 \mathrm{mg} / 100 \mathrm{~mL}$, Cinnamic acid at the peak of No. 2 was $0.58039 \mathrm{mg} / 100 \mathrm{mLl}$, Hydrocinnamic acid at the peak of No. 3 was $0,27228 \mathrm{mg} / 100 \mathrm{~mL}$, Gallic acid at the peak of No. 4 was $1.20214 \mathrm{mg} / 100 \mathrm{~mL}$, Ascorbic acid at the peak of No. 5 was $0.42864 \mathrm{mg} / 100 \mathrm{~mL}$, galacturonic acid at the peak of No. 6 was $0.63040 \mathrm{mg} / 100 \mathrm{~mL}$, Geranic acid at the peak of No. 7 was $0,0245 \mathrm{mg} / 100 \mathrm{~mL}$ and Chirysammic acid at the peak No. 8 was $0.19767 \mathrm{mg} / 100 \mathrm{~mL}$. According to Iltrat and Zarnigar (2013), cinamic acid is a compound antiseptic and as a disinfectant and developed in the industrial world and a compound antroquinone, while the types of other acids such as ascorbic acid or vitamin $\mathrm{C}$ is a strong antioxidant that can limit the damage caused by free radical oxidation on leukocyte. Bioactive components contained in aloe vera skin functions as an antioxidant. Munoz et al. (2015) explain that aloe vera is a CAM plant, most organic acid detected is malic acid Acidity was similar in gel and in pressed cake ( $\mathrm{pH} 5.24$ in gel). The relative malic acid content detected was $0.07 \%$ in gel.

\section{REFERENCES}

Arunkumar, S., \& Muthuselvam, M. (2009). analysis of phytochemical constituents and antimicrobial activities of aloe vera 1 . Against Clinical Pathogens. World Journal of Agricultural Sciences, 5(5), $572-576$.

Astill, C., Birch, M. R., Dacombe, C., Humphrey, P. G., \& Martin, P. T. (2001). Factors affecting the caffeine and polyphenol contents of black and green tea infusions. Journal of Agricultural and Food Chemistry, 49(11), 5340-7.
Braud, L., Peyre, L., de Sousa, G., Armand, M., Rahmani, R., \& Maixent, J. M. (2015). Effect of brewing duration on the antioxidant and hepatoprotective abilities of tea phenolic and alkaloid compounds in a t-BHP oxidative stress-induced rat hepatocyte model. Molecules. 20: 1498515002.

DOI:10.3390/molecules200814985

Choi, S., Chung, M.H. (2003). A review on the relationship between aloe vera components and their biologic effects. Semin Integr Med, 1, 53-62.

Coopoosamy, R. M. (2002). African journal of biotechnology. African Journal of Biotechnology, 9(43), 7289-7294.

Figueroa, T.T.H,. Rodriguez, E., Muniz, E.J.S. (2004). El té verde uma buena elección para La prevención de enfermedades cardivasculares. Archivos Latinoamericanos de Nutrición, 54(4), 380-394.

Fulder, S.(2004). Khasiat Teh Hijau. Penerjemah: Wilujeng, T.R. Prestasi Pustaka Publisher, Jakarta.

Hamman, J.H. (2008). Composition \& applications of aloe veraleaf gel. Molecules, 13, 1599-1616.

Iltrat, M., \& Zarnigar. (2013). Aloe vera: a review of its clinical effectiveness. International Research Journal of Pharmacy, 4 (8), 75-79. DOI: $10.7897 / 2230-8407.04812$.

Kara, M., Sahin, H,, Turumtay, H., Dinc, S., \& Gumuscu, A. (2014). The phenolic composition and antioxidant of tea with different parts of sideritis condensate at different steeping conditions. Journal of Food and Nutrition Research, 2 (5), 258262. DOI: $10.12691 /$ jfnr-2-5-8 
Luthar, Z,. Kreft, I. (1999). Influence of temperature of tannin content in different ripening phase of buckwheat (Fagopyrum esculentum Moench) seeds. Fagopyrum, $16,61-65$.

MacAdam, J., \& Grabber, J. (2002). Relationship of growth cessation with the formation of diferulate cross-links and $p$ coumaroylated lignins in tall fescue leaf blades. Planta, 215(5), 785-793. https://doi.org/10.1007/s00425-002$0812-7$

Mache, A. G., Guiama, V. D., \& Mbofung, C. M. F. (2015). Optimization of total polyphenols and tannins content during extraction of Khaya tea ( Khaya senegalensis ): Effect of water volume, temperature and infusion time. International Journal of Innovation and Applied Studies, 12(3), 659-675.

Matsubara, S., \& Rodriguez-Amaya, D. B. (2006). Teores de catequinas e teaflavinas em chás comercializados no Brasil. Ciência E Tecnologia de Alimentos, 26(2), 401-407. https://doi.org/10.1590/S0101 20612006000200024.

Miranda, M., Maureira, H., Rodriguez, K., \& Vega-Galvez, A. (2009). Influence of temperature on the drying kinetics, physicochemical properties, and antioxidant capacity of Aloe vera (Aloe barbadensis miller) gel. Journal of Food Engineering, 91: 297-304. DOI:10.1016/j.jfoodeng.2008.09.007

Narsih, Kumalaningsih, S., Wignyanto, \& Susinggih Wijana. (2012). Identification of Aloin and Saponin and Chemical Composition of Volatile Constituents from Aloe vera (L.) Peel. Journal of Agriculture and Food Technology, 2(5), 79-84.
Pastore, RL,. Fratellone, P., (2006). Potential health benefits of green tea (Camellia sinesnis): A Narrative Review, 2(6), 531539.

Purnomo, H., Jaya, F., \& Widjanarko, S. (2010). The effects of type and time of thermal processing on ginger (Zingiber officinale Roscoe) rhizome antioxidant compounds and its quality Ginger Phenols. International Food Research Journal, 17, 335-347.

Saklar, S., Ertas, E., Ozdemir, I. S., \& Karadeniz, B. (2015). Effects of different brewing conditions on catechin content and sensory acceptance in Turkish green tea infusions. Journal of Food Science and Technology, 52(10), 6639-6646. https://doi.org/10.1007/s13197-0151746-y

Shonisani, N. (2010). Effect of brewing temperature and duration on quality of black tea (camellia sinensis) and eual (50:50) combination of bush tea (athrixia phylicoides dc.) and black tea. faculty of science and agriculture (school of agricultural and environmental sciences) at the university of limpopo.

Su, X., Duan, J., Jiang, Y., Duan, X., \& Feng, C., (2007). Polyphenolic Profile and Antioxidant Activities of Oolong Tea Infusion under Various Steeping Conditions. International Journal of Molecular Sciences, 8(12), 1196-1205.

Theppakorn, T., Luthfivyyah, A., \& Ploysri, K. (2014). Simultaneous determination of caffeine and 8 catechins in oolong teas produced in Thailand. International Food Research Journal, 21(5), 2055-2061. 